\title{
MEXICAN EXPERIENCE ON MIGRATION AND DEVELOPMENT 1990-2013
}

Rodolfo García Zamora*

\begin{abstract}
After 40 years of a long rising emigration from Mexico to the United States, the number of Mexicans increased to 12 million in 2006, while the increased input of remittances reached $\$ 26$ million dollars in 2007. Yet, the increasing migration and remittances mainly in Zacatecas and Michoacan states do not achieve economic and social development because of the persistent backwardness, unemployment and marginalization. It demands the need for new Policies of Development, Migration and Human Rights that allow exercising the right to not emigrate in a medium term. Positive products of this long migration are the Mexican Migrant Clubs and their Federations that elaborated the concrete development proposals. Whereas, the possibility that these proposals can become a Development, Migration and Human Rights, Comprehensive and Long Term State Policy will depend on the capacity and participation of Mexican Civil Society and the Transnational Communities in both countries.
\end{abstract}

Keywords: migrant clubs, international migration, governmental programs, remittances.

\section{Summary}

Zacatecas and Michoacán, two states characterized by their high international migration due to 40 years of growing migration to the U.S.A reaching figures of 12 million immigrants in 2006, a large increase from the 800,000 in the 1970 's, have taught us that a large amount of immigrants and an increasing number of remittances (26 million dollars as of 2007) are not enough for social and economic development. Unemployment, marginalization and lack of progress are the true root causes of migration, whichkeepcausing us to rethink new policies for Development, Migration and Human rights, which will cause no immigration in medium term.

\footnotetext{
* Universidad Autónoma de Zacatecas. Zacatecas/Mexico.
} 
Some of the positive side effects of this widespread migration are the Federations of Migrant clubs in Zacatecas and Michoacán, among some of their more recognized achievements are: the $3 \times 1$ program, their input in new governmental programs geared towards migrant communities, participation in international forums concerning migration and development. Recently (2010-2013) these federations have participated in new proposals for Immigration reform, which would include migration as a key point in the National Plan for Development for 2013-2018. The possibilities of success of these proposals to become long-term policy in development, migration and human rights will depend on the active participation of both Mexican society and the transnational communities in both countries.

\section{Migration, remittances and development in Mexico, 1990-2012: Lessons and challenges for the future}

In a contemporary Mexican context of profound economical, social and security crisis, it becomes a pressing matter to rethink our economic and governmental policies to recover a sense of peace, social cohesion and credibility in public and private institutions (press, economic sector etc.), employment and stability (health, education, culture, safety, economic well being) whichmust be the axis of all policies.

Mexican Government must be reorganized and recover its function as a guaranty of the nations resources and patrimony, promoter of economic and social development committed with the eradication of poverty and inequality, transparent democracy, accountable and committed to the disappearance of institutional corruption and impunity ${ }^{1}$.

México's high immigration challenge, as is with the rest of Latin American countries, is based on building solid state policies on development and migration, integral and long-term, that strengthen internal markets, different productive sectors, local regions and the capacity to generate decent jobs and well-being throughout the population through new economic development projects that will allow the population the possibility of immigrating as an option to live a better life and not a necessity as it is currently ${ }^{2}$.

The 1980's immigration to the U.S.A. has been proportional to Mexico's economic crisis leading it to a constant growth until 2006.This constant growth in immigration in these past yearscan be mostly explained by the ongoing economic crisis in Mexico and a long period of economic

\footnotetext{
${ }^{1}$ GARCÍA ZAMORA, Rodolfo. Crisis, migración y desarrollo. Los actores sociales y el reto de las nuevas políticas públicas en México, p. 203.

${ }^{2}$ IDEM. Migración internacional y desarrollo en América Latina y el Caribe. Del mito a la realidad.
} 
growth in the U.S.A which served the role of an "escape valve" for all of Mexico's structure, employment, income and general wellbeing 3 .

During Vicente Fox's mandate (2000-2006), each year 575 thousand Mexicans, more than 3 million total immigrated to the U.S.A. This caused, among other things a decline in population in hundred of communities in at least 600 municipalities of great migrant tradition, these municipalities showed a negative demographic growth. Thus, during this period the percentage of women abandoning the country in search of the American dream grew to $45 \%{ }^{4}$.

The growing tendency towards U.S migration was maintained during the first year in office of Felipe Calderon, according to data by the National Population Council for 2007. Ithas beenestimated that 679,611 Mexicans established themselves in the U.S. ${ }^{5}$. These tendencies are ratified by the World Bank $^{6}$, which show that inthe past years, 644,361 Mexicans have left the country on a yearly average. This shows that Mexico has expelled $10 \%$ of its population.

Nevertheless, in the summer of 2011 several International Migratory publications have shown that migration between U.S.A and Mexico has had a historic change in migratory tendencies; this change has never been seen in the last 40 years due to its substantial reduction in magnitude. According to data by the Pew Hispanic Center, less than 100,000 undocumented aliens crossed into the U.S in 2010, much less than the 525,000 annual nations who immigrated to the U.S between 2000 and 2004. This highlights how after a continuous drop in migratory flow in the last 2 years, the undocumented population in the U.S has maintained itself at 11.2 million. This number represents a drop of a million in relation to 2007 when the number of immigrants reached as high as 12 million. The impact of the U.S economic crisis and a stricter border control are the main causes of this drop. Still, the undocumented population represents triple the number in 1990 and among this number, the undocumented population of Mexican origin is the most abundant with 6.5 million immigrants.

This new tendency led to a debate over the conjectural or permanent character of "migration zero". The relevant issue of this debate is Mexico's great fragility to its neighbors economic crisiswhichcomes into question after decades of structural reforms which haven't been able to eradicate migrations root causes, or the enormous dependence on the U.S's economic cycle. Thus

\footnotetext{
${ }^{3}$ IDEM. Desarrollo económico y migración internacional: los desafíos de las políticas públicas en México, p. 309.

${ }^{4}$ Cf. La Jornada, March $4^{\text {th }} 2008$.

${ }^{5}$ Cf. Reforma, September $24^{\text {th }} 2008$.

${ }^{6}$ Cf. Milenio, January $24^{\text {th }} 2008$.
} 
the U.S. stop working as a "safety valve" for Mexico and causes us to rethink the direction of the countries model towards employment, income and wellbeing?

In this new migratory context between Mexico and the U.S., Arroyo, Berumenand Rodríguez ${ }^{8}$ established a challenge toward Mexican society and government to search for an endogenous development where in policy must generate the conditions so that there shall not be a new generation of Mexicans looking to the North as the only alternative for social mobility. Policy should be instrumented towards local and regional development focused on reducing the socioeconomic impacts of lowered remittances and migration, specially the pressure of searching for employment for those who return and to ease the load on those who wish to enter the workforce without the need to migrate to the U.S, at least not in thepast conditions.

It's thus that Agustin Escobar ${ }^{9}$ proposes 3 objectives which migration and development policy should have in the following years: 1) Real incentives to be repatriated(employment, income, housing, education); 2) Ease Mexicans access to basic patrimonial wealth (employment, education, health, elderly care etc.); 3) Having the appropriate tools towards what is required. To morph millions of immigrants to be agents of change in their regions and villages with, goodhearted but symbolic and insignificant programs simply cannot be done. Government needs to step in with the appropriate fiscal resources and a economic policy that allows for a much needed economic growth. Public programs like Ramo 33 and Sagarpas rural development should be taken advantage of, albeit with a focus on regional development and employment.

According to Francisco Alba $^{10}$, a medium term perspective must reflect on the convenience of including its economic policy objectives retaining and occupying the population in a productive way in its own territory. This means placing migrations in the center of economy and politics, that is, "migrating" local policy.This migration of social and economic policies are created as a development strategy that allows a modification of the continuity of emigrational patterns which are hard to qualify as historically successful or acceptable.

Mexico, strangely, even through its long history of internal immigration towards the U.S. initiates its governmental policies and programs for its iimmigrants until the 1980 's due to pressure from organized migrants.

\footnotetext{
${ }^{7}$ GARCÍA ZAMORA, Rodolfo. Cero migración: Declive de la migración internacional y el reto del empleo nacional

${ }^{8}$ ARROYO, Jesús; BERUMEN, Salvador; RODRÍGUEZ ALVARES, David. Nuevas tendencias de largo plazo de la emigración mexicana a Estados Unidos, p. 43.

${ }^{9}$ ESCOBAR LATAPÍ, Agustín. Las políticas públicas mexicanas y la migración entre México y los Estados Unidos. Un enfoque binacional.

${ }^{10}$ ALBA, Francisco. Respuestas mexicanas frente a la migración a Estados Unidos, p. 536.
} 
Among its most important acts and programs we find ${ }^{11}:$ 1) National Council for Communities Abroad; 2) "Paisano" Program; 3) Institute for Mexicans Abroad; 4) Bansefi Remittance transfer Program; 5) 3x1 Program; 6) Council for the promotion of business between Mexican and Hispanic Communities; 7) Binational Migrant Education Program; 8) Binational health program (go healthy, return healthy), Popular health insurance for migrant families; 9) Temporal Workers Program ( $\mathrm{H} 2 \mathrm{a}$ and $\mathrm{H} 2 \mathrm{~b})$ and the Labor Cooperation Agreement of North America; 10) Migrant Care National Coordination Office (CONOFAM); 11) Population, Borders and Migratory Affair Commissions for the Chamber of Deputies; 12) Migratory Commission for Governors National Coordination (CONAGO); 13) Mexican Talents Network; 14) 1x1 Program for Migrants, Social Development, Agriculture, Livestock and Fisheries Secretariats (Sedeso and Sagarpa).

These initiatives highlight the reactive character of complaints and proposals by the migrant community, its partiality and lack of articulation of policies related to regional and local development; and a lack of focus towards employment and link towards their original regions and communities. It becomes evident that emigrational and development politics are not being designed in a coherent or adequately contextualized manner, that these policies could be written in a alternative model of development and in a new plan for regional economic integration capable of reducing the socioeconomic asymmetries between Mexico and the U.S to help reduce the migratory dynamics prevalent nowadays ${ }^{12}$.

With the economic crisis of 2007-2011, the need for designing proactive public policies grew, that permitsa way out of stagnation and adequately articulate plans and development programs with the appropriate countries over migration. The purpose was to revert the impacts of the economic crisis and build solid bases of regional development. In the last 10 years, in different national and international forums, the debate has raged on over the connection between migration and development, the consensus reached has emphasized the need for pubic development policies, so that the positive impacts of migrations can have a relevant effect over social and economic development in the countries and regions from where most immigrants are from.

Iln the pre-economic crisis international forums, the migrant organizations have repeatedly demanded recognition as a new actor in transnational development, this request was ratified in the global forums of migration and

\footnotetext{
${ }^{11}$ GARCÍA ZAMORA, Rodolfo. Políticas migratorias con enfoque de empleo para México y Guatemala.

12 IDEM. Desarrollo económico..., op. cit.
} 
development which took place in Brussels, Manila, Athens and Puerto Vallarta in 2007, 2008, 2009 and 2010 respectively. The challenge remained on how to build these new public policies of migration and development between every transnational party, including of course migrant organizations. In the very specific case of Mexico the main goal is to contribute both in practice and design of the federal budget of "Ramos 26, 28 and 33" which contain the main financial transfers between federal state and municipal governments.

IIn the last 10 years, Mexican migrant organizations have initiated a process of institutional strengthening, collaboration and definition of a strategy for alliance with other social participants which coincide with the objectives of promoting a new type of public policies on migration and development. This process can be explained both by the maturing of some migrant organizations after years of financing hundreds of social projects and establishing dialogue and negotiations between the three levels of government, international organisms, institutions of higher learning and non governmental institutions. Thus, due to the structural lag in communities and the impact suffered by the economic open market and privatizing model established in Mexico since 1982 and the effects of the economic crisis in the U.S since 2007 have shown the necessity to the Mexican migrant organizations to collectively build a common agenda and a common strategy of a holistic migratory view that includes sustainable human development and human rights, these stem from new public policies.

As said before, the federations of migrants from Zacatecas and Michoacán are those which, due to their history, have had a larger presence in the design of new governmental policies and programs for migrants, and are the ones that have participated in all the great worldwide forums pertaining to migration and had the development in the last years working with organized civil groups in Mexico for a new Immigration Reform and the inclusion of the topic of migration, development and human rights in the National Plan for development 2013-2018.

We shall review their legacy and contributions of each one of them without attempting to fall in a certain confusion where the immigrants are responsible for the development of their home regions and communities. But if they are interested in collaborating in this objective, public policies should be made in an adequate manner for economic development on a local, regional and national level, strengthening the counties and especially back any action which help the communities so that they become main actors in their own development. 


\section{Zacatecas: Lessons and Challenges in international migration}

The state of Zacatecas, with more than 100 years of migratory history to the United States has one of the most important experiences in Mexico showing the impacts on the economic, social and political structure on the state level of this phenomenon and all the different types of remittances received. This long international migratory tradition explains the existence of the most important Mexican migratory organization in the United States, more than 200 club of Zacatecas natives, whom with a profound solidarity have financed with the 3x1 Program, with collective remittances, over 1500 social programs in home communities since 1993(under 2x1 modality) to 2004, once established as a national program.

These organizations along with their home communities, Zacatecas society and the state government, have stood up to the collective challenge that is to transit through a multiple action philanthropic phase towards a phase of local and regional transnational development, in which the home communities and their clubs can take on an important supportive role in the fundamental labors of the Mexican state, of promoting regional economic development, this is, while they are capable of achieving a qualitative change in the organization and capability with a strategic vision of transnational development. The institutes of higher learning and non governmental institutions can play a relevant part of collaboration and institutional assistance in this qualitative process and the strategy for development ${ }^{13}$.

The structural economic weakness of Zacatecas, of which itsGDP does not surpass $1 \%$ on a national level in the past 4 decades, the largest rate of migratory intensity (700, 000 migrants to the USA respective to the 1.4 million natives from Zacatecas in the state), andthe greatest percentage of receivers of remittances in the country and one of the greatest levels of depopulation on a national level in home communities (60\% of municipalities in 2005), explain how international migration in the state plays a large role in its economic and social growth. This explains the relative leadership to promote actions in favor of migrants and their home communities. Amongst these actions we can name: 1) Creation of the $2 \times 1$ Program of collective remittances in 1992; 2) Creation of the Office for Migrant Care in 1992; 3) Transformation of the $2 \times 1$ program to $3 \times 1$ in $1999 ; 4)$ Involvement in the establishment of the $3 \times 1$ program on a federal level in 2002; 5) Establishment of migrant deputies in 2004; 6) Funding of the binational Chamber of Migrant Zacatecan Entrepreneurs in Illinois, 2005; 7) Involvement to establish the 1x1

${ }^{13}$ IDEM. Migración internacional y remesas colectivas en Zacatecas. 
Productive Program 2009; 8) Involvement to establish the 2x1 Productive Program in Zacatecas 2010; 9) Funding of the binational Chamber of Migrant Zacatecan Entrepreneurs in California, 2010; 10) Promoting the $3 \times 1$ program in El Salvador, Ecuador, Philippines, Somalia and Haiti; 11) Participation in every Social and Global Forum over migration and development. Since 2006.

These actions and advances are achieved through the growth of migrant clubs in the U.S and its formation into federations, Southern California and Illinois are the pioneers and mentors of Texas, Colorado, Northern California and Las Vegas in this endeavor. This structural organization has allowed a participation in a transnational learning process of lobbying on a municipal, state, federal and worldwide level. Starting in the first stages of financing the different 3x1 programs, modifying operation rules, including new areas of financing such as scholarships and productive projects and on a global scale, in many forums over migration and development, in which the southern California and Illinois Federations have debated making proposals over the design of new public policies on migration and development from Brussels in 2006 to the Mauricio Isles in 2012 going through Philippines, Athens and Mexico in previous years.

In these transnational organizations, their learning curve and leadership have emerged as a social actor in development; in 2007 a greater challenge was established to the Zacatecas Government which was to establish for the first time a state policy on regional development and migration that brings together all the social stakeholders, specially the home communities and its migrant organizations ${ }^{14}$.

As formally stated, the State Proposals for Development of 1999-2004 and 2005-2010 set forth by Ricardo Monreal and Amalia Garcia aspired to develop a state policy on migration and development placing Zacatecas at the national vanguard in the design and execution of programs and projects for integral long term development, with the participation of the migrant community setting forth proposals for the democratic planning of local and regional development, transparency, institutional growth and accountability.

Unfortunately, the plans andobjectives were not accomplished and, in general, the plans were implemented in a traditional pragmatic way, with weak governing boards, without experience or credentials for the creation of a new institutional development in the state. Both governors, just as in the case of the current Governor, dedicated themselves to administer federal programs with great publicity expenses to their personal images, and ignored

${ }^{14}$ IDEM. Migración internacional y desarrollo. Oportunidades y desafíos para Zacatecas. 
any participation of the economic stakeholders in the planning of any economic or social governmental action.

In essence, the structural economic lag, depopulation, aging and feminization of the home communities has been maintained as well as a growth in rural economic crisis and a centralization of $60 \%$ of the GDP in the municipalities in Zacatecas, Guadalupe and Fresnillo. The endogenous bases of economic state development have been found lacking, no strategy exists for the construction of a new institutional development and the state continues, just as it has been for a 100 years, to export minerals and labor force.

Zacatecas has turned into an important global social laboratory of international migration, showing its contributions and limits. Migration has temporarily attenuated the structural contradictions of marginal communities, unemployment and general backwardness. Thus, even though it has gone through more than 50 years of a enormous international migration and various remittances that cannot produce development, it grows in the "development of sub development". It becomes highly dependent and vulnerable on the regions and families of remittances as shown during the US crisis in 2008-2013, when Zacatecas receives more than 100 million dollars a year, the state government becomes irresponsible and ignore any of their obligations to promote economic and social development and promote public policies of development with a scope on law; and migration as an extra activist activity goes against the most valuable resource which is state population $^{15}$.

Even through the division between state development plans from 1999-2010 and governmental practice, many of its objectives remain such as: given how small the business sector is in Zacatecas, the state has to be the promoter for regional and sectorial economic development strengthening in first place the regional productive structure and the generation of permanent and well played jobs; the institutional change is strongly needed that permits going beyond a simple administration of federal programs and makes the construction of a new institutional development viable in the different economic regions and sectors of the state.

This requires that planning stops being rhetoric and becomes permanent practice in the state and municipal administration with properly trained personal who have the experience to create for the first time a state policy on migration and development. Only in this way can the Strategic Committee for Development (Copladez), the Regional Strategic Committee for Development (Coplader)

$\overline{15}$ IDEM, Crisis, migración..., op. cit., p. 270. 
and the Municipal Strategic Committee for Development (Coplademun) work, whichuntilnow have only existed on paper and in rhetoric.

Every higher learning institution must participate in a true State Council for Science and Technology, that may serve as scientific support in the economic and social state development. The business sector and the bi-national chamber of migratory entrepreneurs must participate in a permanent fashion in the planning, execution and evaluation of the different governmental plans and programs.

The migrant organizations will be very important in the design for social policies in education, health culture, nutrition and reinsertion with a transnational focus. Zacatecas has the possibility to keep onbeing on the vanguard of the $3 \times 1$ program if it focuseson a regional and local transnational development strategy. Migrants and their organizations must be the axis on which to design specific programs with migrant investment that respond to its different profiles, resources, experience, motivations etc. Overcoming the vertical design of investment programs which have had till now small success.

\section{Michoacán: Contributions and challenges in migratory policies}

The state of Michoacán, places in the Midwestern historical region of international migration to the United States, like many other states, has more than 100 years of migratory experience to this country. Gustavo Lopez Castro $^{16}$ mentions how in the last decades international migratory flux takes on a great dynamic character in the great changes of the traditional migratory pattern towards a new pattern of permanent family migration, this stems from, amongmany other things, the impacts of Immigration Reform in the U.S in 1986 (IRCA), reoccurrence of economic crisis and solid social nets built for decades in the U.S.

On his part, Héctor Rodríguez Ramírez (2003) ${ }^{17}$ highlights the following characteristics of migration from Michoacán: Between 1990 and 2000, slightly more than 370,000 natives from Michoacán migrated to U.S., this represents a $9.4 \%$ of the states population in 2000 . Going by the number of households with at least one migrant between 1990 and 2000, it can be shown that the state registers the second highest rate of migratory intensity in the country after Zacatecas. In the 1990's, 15\% of Michoacán homes had at least one migrant member.

Michoacán is the only state in the country where $100 \%$ of its municipalities have migrant households. According to the National Council of

\footnotetext{
${ }^{16}$ LÓPEZ CASTRO, Gustavo. Migración, desarrollo y regions.

${ }^{17}$ RODRÍGUEZ RAMÍREZ, Héctor. Migración internacional y remesas en Michoacán.
} 
Population (2002), of the 113 municipalities, 25\% are classified as very high migratory intensity, 28\% high intensity and 30\% at a medium level. Regionally the greatest flux occurs in the areas that border Jalisco and Guanajuato, which represent $49.7 \%$ of Michoacán migrants, these regions also encapsulate more than $40 \%$ of households with at least one migrant in the 1995-2000 period.

TThe most evident economic impact of this great migration is the remittance flux, according to Conapo in $2000,11.3 \%$ of state homes receive these remittances. More than 100,000 homes receive remittances, on average they represent $56.2 \%$ of incomes for the families back home. In one of three homes, remittances are the only source of income. In more than a third part of municipalities of the state there is a high percentage of remittance-receiving homes whose only source of income is this flux of currency, six out of 10 homes are in this situation ${ }^{18}$. On a social and political level, the impacts of Michoacán migration are manifested in an important network of transnational migrant organizations in the U.S., the strongest federations among these migrant organizations are the ones in Chicago and L.A, California; they represent in a significant way the birth of Zacatecan clubs that in the 1960's came out as philanthropic organizations that provided mutual help and protection, then they spontaneously transited to a role of solidarity in social projects in their home communities, and, finally in the 1990 's slowly begun to participate in the 3x1 program, and in its national stage as of 2003 their participation grew to pioneering the impulse of projects relating to rural migrants (greenhouses).

During the first decade of the 21st century the capacity of involvement of municipal, state and federal governments, in particular with the Social Development Office, grew responsible of the $3 \times 1$ program. This explains the advances in state programs and the changes in the state constitution in answer to the proposals and demands of migrants, some of them are:

- Establishment of an Office for the coordination of migrant care that finally transforms into the Secretariat for Migrant care of Michoacan, 2002-2010

- Creation of the Michoacan House in Chicago and support to varied activities of advertising, organization and training of the Michoacan Federation in Chicago.

- Help and support to the $3 \times 1$ program with an emphasis on productive projects for rural migrant families.

- Involvement in changing the rules of operation for the $3 \times 1$ program on national level with a greater migrant participation and transparency in its execution.

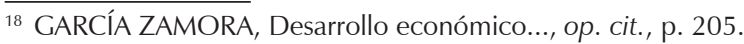


- Establishment of Communitarian Development Committees (CODECOS)

- Establishment of Municipal Attention Centers (CAM) for migrants and their families.

- Changes in the state constitution to allow the election of migrant deputies and Mayors, as well as governor elections.

Even through the important achievements done in programs for the care of Michoacan migrants, like the creation of the Migrant Care Secretariat, there still exists a ruptureamong the state dependencies responsible for economic policy, the people responsible for social politics and those who attend to migrants. It has not been possible to come to a vision from which the migrant can be involved as an acting agent in the development process as has been seen repeatedly by migrant leaders in Michoacan, Mexico and the World; a sectored idea persists that migrants must be taken care of from a different sector with reactive and charitable actions; true political will to build real public policy has not been had to create long term advances in development, migration and human rights.

With these limitations and exploiting the advances that state administrations have had since 2002 to 2013, a local development proposal with a transnational focus for Michoacan implies generating a new vision for governmental development, migration and human rights policies, with an active participation by migrants, their families, municipalities and communities to advance in a true public policy concerning local development and migration with the participation of all economic and social sectors.

It is of utmost importance to place development and migration as main axis of state administration and establish a permanent collaboration between municipal and state dependencies and local and foreign transnational communities - for the design and application of new policies, projects and programs of local development with a transnational focus so that it can integrate in a coherent way into the migrant department in local and regional development programs with the departments of economy, social and rural development to adequately articulate a regional development plan for sustainability, migration and administration of the territories.

It is necessary to reorient the application in the state of "Ramos 26, 28 and 33" of the federal budget towards regional development and employment and to take advantage of the Committees for Community Development and Municipal Support (CODAECOS and CAMS) as a support in a local development strategy with a transnational focus, joining them with migrant organizations, higher learning institutions, private sector and other civil society organizations. 
Taking into account all of this it becomes possible to design a strategy to strengthen community leadership for local development with a territorial and transnational focus in the regions of larger migratory intensity in Michoacan and its communities organized into state, taking advantage of the cybernetic platform that is Virtual University and the support of all the higher learning institutions, state and federal dependencies and international organisms like UNESCO, FAO, IAF, IAD, BID and others.

The Michoacan Cocyt must give a privileged spot to thesis, investigations and human resources that strengthen local development with a transnational focus, also in popular micro finance with the same focus; business incubators for migrants and their families; courses in micro startups for migrants and their families, projects for popular economy and solidarity with a transnational focus; and the construction of a network that searches for transnational talent for local development.

It will be required to take advantage and strengthen the "Bi-national Education Program", strengthen and exploit the "Bi-national Health Program" and design a support program for the reinsertion of the migrant and his family with a focus on human rights in the state.

\section{New migratory policies and transnational civil society}

As a result in the substantial increment of transmigration of central Americans and other countries through Mexico to the U.S and the growing amount of violence and human rights violations by all kinds of public safety institutions and criminal organizations, a need is established to create new immigration reform in 2010, the last policy depended on "Population Law" which harkens back to the 1970's.

This begins a slow and torturous discussion process with the dependencies of State Department, the department is responsible for creating the proposal for this new law, whichrepeatedly insists on a national security focus and a criminalization of migrants. It was the participation of organizations of Mexicos civil society like the INEDIN, Sin Fronteras, Inmumi, Fundar, Iniciativa Ciudadana, Incide Social, la Red Mexicana de Organizaciones y Lideres Migrantes and Nalacc, that made it necessary to incorporate a focus on human rights in this new Law to promote a drastic change in the National Institute of Migration, the Mexican governments office responsible for transmigration and accused of multiple misdeeds and corruption throughout the country.

The process in this new law took more than 2 years due to it being part of the corresponding Ruling and due to the government's apathy who took more than a year to approve. This new law and its ruling still have a focus 
on national security and even though it includes general declarations on the respect towards migrants and their families, including a focus on human rights, social control and changes in the INAMI and other official dependencies connected to transmigrationsthanks to their proposals and pressure of the aforementionedcivil society transnational organizations, the practice prevails to have a great discretion on politicians side to put the law into practice; the designation of unprepared officials also remains; violence and corruption in the INAMI and other security organizations in the country that keep viewing migrants not as human beings but as exploitable commodity and a permanent source of extortion.

It is important to show a previous attempt by civil society to include a human rights vision in the new immigration reform, the Mexican network of leaders and migrant organizations in the U.S had a very important participation, some of the most important organizations came from Zacatecas, Michoacán, Durango, Yucatan and Oaxaca. This network shows a process of institutional maturity and an alliance with migrant organizations and other social organizations in Mexico and U.S. On march 15th 2011, through alliances of ONG's and other academic institutions or international foundations, the Mexican Forum in Mexico city proposed a migrant Agenda with four central points (García R. 2012 b, 228 $)^{19}$ : 1) Full political rights in Mexico for migrants and their families; 2) Immigration Reform in Mexico and an cease in deportations from the U.S.; 3) Design for a State policy on development and migration in Mexico; 4) Institutional strengthening of transnational clubs and communities.

\section{National Development plan 2013-2018 and a Collective PND Migration and its proposals}

Partly as a result of the participation of $\mathrm{NGO}^{\prime} \mathrm{s}$ in the design of a new migration Law and its bylaws during the period of 2010-2012, several organization in the U.S and Mexico, including several researchers with years of work dealing with migration, development, human rights and public policy, when the NDP (national development plan) is initiated, the necessity is perceived to participate in this process and share with different forums an integral political state proposal on development, migration and human rights.

Stemming from this, the collective NDP-migration with NGO's all over the country and the U.S. take shape on the 16th and 17th of February in Mexico City, after 2 months of consulting, interviewing and internal labor during the debate, and formulating proposals finally the "Strategic Transnational Migratory Agenda for the National Development Plan 2013-2018" is published.

${ }^{19}$ GARCÍA ZAMORA, Crisis, migración..., op. cit., p. 228. 
The collective NDP-Migration ${ }^{20}$ is a wide and plural group made up by civil society organizations that work on the topic of migration focusing on human rights, gender, sustainable development and cultural plurality. Their objective is the inclusion of the topic of migration in a primary character in the National Plan for development 2013-2018 through participation mechanisms that would be inclusive, transparent and democratic, and through a strategic transnational migration agenda that takes advantage of the 83 organizations that conform the collective experience and hard work.

The member of the collective characterize, amongst other things, by the integral focus on migrants rights, with the intention of bettering the life of the migrant population, asylum requests, refugees and their families in wherever they must transit, originate, return or finally settle down in. They seek to promote the democratic participation in the creation of the NDP and collaborate in the construction of a state policy that places the topic in a main focus on human rights, gender, sustainable development and multiculturalism. The need to recognize the structural causes of migration is shown, by which new public policies of development, inclusion and equality are needed. These must begin with an ample dialogue with participation coming in from civil society, migrant population and their families, which the Mexican State must promote with accountability and transparency.

To the collective, migratory policy refers to a coordinated set of actions that guarantee the wellbeing of migrants, including the free exercise of their rights, the possibility to migrate or stay in their home communities, in a environment free of violence; this must be guaranteed by the Mexican State. Policies must be multidimensional and intersect in their implementation, and orientation by objective, goals and clear indicators. Some of the factors to be considered are to include the population of origin, return, destination and transport; the diaspora and the population that seeks recognition of their refugee status, also planes must be incorporated that ease the access for migrants, including those who migrate back in the social life of the country and mechanisms that guarantee the protection of their rights.

The collective NPD-Migration proposes 3 structural causes that lead into the emigrational phenomenon:

1. Social and economic fragility in home communities, derived from a predator economic model that annihilates economic and social bases, communitarian life and the environment.

\footnotetext{
${ }^{20}$ Colectivo PND-Migración. Agenda Estratégica Transnacional de Migración para el Plan Nacional de Desarrollo 2013-2018.
} 
2. Discrimination and rejection of several sectors of society towards migrants, their defenders and human rights

3. Increasing violence towards migrants and their families both on account of official security corporations as well as criminal organizations that have found in them a new sector on which to exact violence and extortion.

If we add to this the vulnerability of migrants and their families during the different stages of migration, associated to varied conjectural problems in labor, economic, social, cultural and political environments. These problems include a lack of opportunities in transnational communities both of destination and origin; the lack of strategic support and an impulse towards development, solidarity, sustainable growth and wellbeing for migrants and their families; and in absence of mechanisms that repair social fabric, impulse the reinsertion of returning immigrants and attend in a integral manner the families of migrants in their home communities.

Limited access to justice for migrant victims and their families, and the absence of basic information on the phenomenon's of violence and repeated delinquency that affect migrants. The increase in violence, women's rights and the murder of migrant women and children; the absence of mechanisms for the protection and obstacles to the access of services to migrant victims of violence.

It is very clear that there is an omission from the authorities in relation to their responsibility in the well-being of children and bythosemigrant children including the children detained during transit, because of the lack of alternatives in care and absence of mechanisms supporting reinsertion and education of the repatriated children, likewise for the violation of labor rights in the schematics of temporal employment; omission and regulatory state incapacity, both for internal and international migration.

With respect to the international policy design and framework 3, problems exist that stop the Mexican state to understand migration and development from an integral rights perspective, the absence of coordination mechanisms that permit an effective articulation on the instances in charge of public administration of the migratory phenomenon, the impunity and inefficiency derived from the lack of mechanisms for accountability of local, state and federal orders; and the omissions and acts of authoritarian violations of human rights of migrants and the complicity of the authorities on every level and governmental orders in the abuse and disappearance of migrants, particularly on a state level.

The main objectives of this Transnational agenda are: 
1. Articulate an integral vision and multidimensionality of the link between migration, development, human safety with the mechanisms that integrate migration in an important way in the NPD.

2. Explicit integration of the migratory phenomenon, connection between migration and development and the functions and obligations of federal public administration to guarantee rights in a national system of accountability.

3. Creation of a inter-institutional coordination structure and amongst the governmental orders in migratory matters, in which citizens, civil society organizations and academics will participate.

4. Creation of a national strategy for the protection, promotion and realization of the rights of migrants and their families. This strategy must includes actions to sensitize authorities of the 3 strata of government about their obligations in relation to the rights of migrants; and establish adequate coordination mechanisms. Conditions of access to justice, explicitly consider the right of identity, health and education, and establish action to combat impunity and promote a culture of respect towards migrant rights.

5. Explicit consideration of migration in sustainable development programs with a base on the notion of well-being, that sets strategies to combat poverty with the principles of inclusion and equality, and orient them towards full realization of social, economic cultural and environmental concerns.

6. An increment in the representation of migrants communities and the mechanisms for the administration and coordination of integral migratory policy.

The collective NPD-Migration had the capacity to participate with proposals in every forum in which the Mexican government promoted the NPD from March to May of this year. Actually, in the first forum, which took place in the Department for Foreign Relations on, March 11th in 2013, the president received an integral proposal from the collective concerning new public policies on migration, development and human rights.

If these proposals are not included in the final version of the plan or are limited to marginally placing them only in the national migration program, that by law must be formulate the new Planning Unit in the State Department, without returning to the integrity as state policy on migration and development with a focus on rights, will mean that the migratory problem is not relevant in the national agenda, neither for the executive, judicial or legislative branches. It will keep on being as it has in the last 40 years, with the same attitude of simply taking advantage of the efforts, hard work and 
remittances (more than 23 billion dollars in remittances), responding to small charitable programs and a great deal of rhetoric in official speeches.

Nonetheless, the efforts made by transnational civil society in the fight for a new framework in the bylaws of the Migration law with a focus on human rights and the proposal of a transnational agenda have not been sterile, a wide alliance of social organization in Mexico and the U.S. has been built with a shared agenda which has a strategic vision of development, migration and authentic transnational governance with a focus on rights, social control and accountability. The fact that this strategy can be gradually incorporated into the design for new public policy with a growing participation of civil Mexican society in the new few years will depend on its strength, participation and on the transnational communities in both countries in coordination with the other sectors that fight to recover employment, income, well being and human security as national priorities.

\section{Conclusions}

Every effort made and told in this text towards the design of new policieEvery effort made and told in this text towards the design of new policies on development and migration, even through, for example, the case of the proposal made by the collective NPD-Migration, included 500 words marginally in the NPD 2013-2018, have not been sterile due to three important products: A wide alliance of organizational social transnational networks, a shared agenda with a strategic and integral vision of development, migration and human rights and a growing process of learning, collaboration and transnational support between social organizations, home and original communities amongst many allies.

Every day these allies grow, due to the fact that we are the most interested in participating in these topics and we are the ones who realize that there is still much to do with migration and development in Mexico, the pressure that can be exercised is giving small triumphs that can be an important factor in the decision making on a governmental scale as can be seen in migrant organizations whom molded a normative change in 3x1 program and new social and productive aspects, but mainly they have an impact on every level by having repercussions in the way the topic is recognized socially and on a worldwide scale.

The Mexican migratory topic is not seen as an isolated phenomenon anymore, but looks towards other experiences in order to have richer alternatives. International and national forums help as a stage to share and create alternatives that enrich every reunion and in Mexico's case the advances 
have been significant as can be shown in joining more than 80 associations, NGO's, academic groups and migratory representatives.

\section{References}

ALBA, Francisco. Respuestas mexicanas frente a la migración a Estados Unidos. In Francisco ALBA, Manuel Ángel Castillo; VERDUZCO, Gustavo. Migraciones Internacionales. México: El Colegio de México, 2010.

ARROYO, Jesús; BERUMEN, Salvador; RODRÍGUEZ ALVARES, David. Nuevas tendencias de largo plazo de la emigración mexicana a Estados Unidos. Papeles de Población, Nueva Época, v. 16, n. 63, enero-marzo, 2010.

Colectivo PND-Migración. Agenda Estratégica Transnacional de Migración para el Plan Nacional de Desarrollo 2013-2018 (versión electrónica), 2013.

ESCOBAR LATAPÍ, Agustín. Las políticas públicas mexicanas y la migración entre México y los Estados Unidos. Un enfoque binacional. Secretaría de GobernaciónInstituto Nacional de Migración-CIESAS, 2008.

GARCÍA ZAMORA, Rodolfo. Migración internacional y desarrollo local. México: U.A. Zacatecas, 2004.

. Migración, Remesas y Desarrollo. Los retos de las organizaciones migrantes mexicanas en Estados Unidos. México: U.A. Zacatecas, 2005.

. Migración internacional y remesas colectivas en Zacatecas. Foreign Affairs en español, v. 5, n. 3, ITAM, Ciudad de México, 2005.

- Migración internacional y desarrollo. Oportunidades y desafíos para Zacatecas. In CALVA, José Luis. Políticas de desarrollo regional. Agenda para el Desarrollo, v. 13, UNAM-Miguel Ángel Porrua-Cámara de Diputados LX Legislatura, Ciudad de México, 2007.

. Desarrollo económico y migración internacional: los desafíos de las políticas públicas en México. México: Universidad Autónoma de Zacatecas, 2009.

- Migración internacional y desarrollo en América Latina y el Caribe.

Del mito a la realidad. In VIDAL, Gregorio; LEÓN, Omar de. América Latina: Democracia, Economía y Desarrollo Social. Madrid: Ed. Trama, 2010.

. Políticas migratorias con enfoque de empleo para México y Guatemala. Madrid: FIIAPP, 2011.

. Cero migración: Declive de la migración internacional y el reto del empleo nacional. Migraciones Internacionales, El Colegio de la Frontera Norte 23, v. 6, n. 4, julio-diciembre, Tijuana, Baja California, 2012.

. Crisis, migración y desarrollo. Los actores sociales y el reto de las nuevas políticas públicas en México. México: Universidad Autónoma de Zacatecas, 2012. . Michoacán: Hacia el diseño de nuevas políticas públicas de desarrollo, migración y derechos humanos. México: Conacyt-Cocyt Michoacán-Universidad Autónoma de Zacatecas, 2013. 
LÓPEZ CASTRO, Gustavo. Migración, desarrollo y regions. Colegio de Michoacán, 2005.

RODRÍGUEZ RAMÍREZ, Héctor. Migración internacional y remesas en Michoacán. LÓPEZ CASTRO, Gustavo. Diáspora Michoacana. Colegio de MichoacánGobierno de Michoacán, 2003.

\section{Resumo}

\section{Experiência mexicana refrerente a migração e desenvolvimento}

1990-2013

Depois de 40 anos de constante aumento da emigração do México para os Estados Unidos, o número de mexicanos residentes naquele país chegou a 12 milhões em 2006, enquanto as remessas atingiram seu ápice em 2007, com 26 milhões de dólares. No entanto, o crescimento da migração e das remessas, principalmente nos Estados de Zacatecas e Michoacán, não produziu o esperado desenvolvimento econômico e social, por causa da persistência do atraso, do desemprego e da marginalização. Precisa-se de novas políticas de desenvolvimento, migração e direitos humanos, que permitam, a médio prazo, o exercício do direito a não emigrar. Um produto positivo deste longo período de migração é a constituição de clubes de Migrantes Mexicanos e suas Federações que elaboraram propostas concretas de desenvolvimento. A possibilidade de que estas propostas se tornem políticas públicas de desenvolvimento, migração e direitos humanos, abrangentes e de longo prazo, dependerá da capacidade e da participação da sociedade civil mexicana e das comunidades transnacionais em ambos os países.

Palavras-chave: associações de migrantes, migração internacional, políticas governamentais, remessas.

Received for publication in August, 22 ${ }^{\text {th }}, 2013$. Accepted for publication in November, 12 ${ }^{\text {th }}, 2013$.

Recebido para publicação em 22/08/2013. Aceito para publicação em 12/11/2013.

ISSN impresso: 1980-8585

ISSN eletrônico: 2237-9843 